\title{
Relationships between body size - otolith size for seven demersal fish species from the Marmara Sea, Turkey
}

\section{Marmara Denizi'nde dağılım gösteren yedi dip balığının vücut ölçüisü-otolit ölçüsüi ilişskileri}

\author{
İsmail Burak Daban ${ }^{*}$ • Mukadder Arslan İhsanoglu² • Ali İşmen ${ }^{3}$ \\ ${ }^{1}$ Faculty of Marine Sciences and Technology, Department of Fisheries and Processing Technology, \\ Çanakkale Onsekiz Mart University, 17100, Çanakkale, Turkey \\ ${ }^{2}$ Faculty of Marine Sciences and Technology, Department of Fisheries and Processing Technology, \\ Çanakkale Onsekiz Mart University, 17100, Çanakkale, Turkey \\ ${ }^{3}$ Faculty of Marine Sciences and Technology, Department of Fisheries and Processing Technology, \\ https://orcid.org/0000-0002-2973-5698 \\ https://orcid.org/0000-0003-0072-5848 \\ https://orcid.org/0000-0003-2456-0232
} Çanakkale Onsekiz Mart University, 17100, Çanakkale, Turkey

Corresponding author: burakdaban@gmail.com

Received date: 27.01 .2020

Accepted date: 11.03 .2020

How to cite this paper:

Daban, İ.B., Arslan İhsanoğlu, M. \& İşmen, A. (2020). Relationships between body size- otolith size for seven demersal fish species from the Marmara Sea,

Turkey. Ege Journal of Fisheries and Aquatic Sciences, 37(3), 267-274. DOI: 10.12714/egejfas.37.3.09

Abstract: The total length-otolith length (TL-OL), total length-otolith width (TL-OWi), total length-otolith weight (TL-OW) and total weight-otolith weight (TWOW) relationships of seven fishes in the Marmara Sea, Turkey were calculated. Measurements of sagittal otoliths (length, width and weight) and individuals (total length and total weight) from these species (Gaidropsarus biscayensis, Mediterranean bigeye rockling; Arnoglossus kessleri, Scaldback; Solea solea, Common sole; Uranoscopus scaber, Stargazer; Lophius budegassa, Blackbellied angler, Lepidorhombus boscii, The four-spot megrim and Lesueurigobius friesii, Fries's goby) were given. Linear regression analysis $(y=b x+a)$ was used to determine the relationship between each morphometric character and the coefficient of determination $\left(r^{2}\right)$ were calculated. Highest determination coefficient were determined for $L$. budegassa and A. kessleri to TW-OW, for S. solea, and U. scaber to TL-OL, for G. biscayensis and L. boscii to TL-OWi, for $L$. friesii to TL-OW. The relatively lower determination coefficients were found for $G$. biscayensis, compared with others. These relationships provide vital information on species identification and size estimation of fish in predator-prey studies, we believe these results will be useful in future studies of stomach contents.

Keywords: Sagittal, bony structures, lineer, length, benthic, beam trawl

Öz: Marmara Denizi'ndeki 7 balık türünde balık boyu-otolit boyu (TL-OL), balık boyu-otolit genişliği (TL-OWi), balık boyu-otolit ağılığı (TL-OW) ve balık ağırlığıotolit ağırlığı (TW-OW) ilişkileri hesaplanmıştır. Bu türlere ait (Gaidropsarus biscayensis, Uzun Gelincik; Arnoglossus kessleri, Pisi Balığı; Solea solea, Dil Balığı; Uranoscopus scaber, Tiryaki; Lophius budegassa, Fener Balığı; Lepidorhombus boscii, Kancaağız Pisi ve Lesueurigobius friesii, Kaya Balığı) balık ölçümleri (boy ve ağırlık) ve otolit ölçümleri (boy, genişlik ve ağırlık) verilmiştir. Her bir morfolojik karakteristiğin arasındaki ilişkilerin tespitinde Doğrusal regresyon analizi $(y=b x+a)$ kullanılmış ve determinasyon katsayısı $\left(r^{2}\right)$ hesaplanmıştır. En yüksek determinasyon katsayısı $L$. budegassa ve $A$. kessleri için TW-OW, S. solea, ve U. scaber için TL-OL, G. biscayensis ve L. boscii için TL-OWi, L. friesii için TL-OW ilişkilerinde hesaplanmıştır. Diğer türlerle karşılaştırılığında, G. biscayensis için oldukça düşük determinasyon katsayıları bulunmuştur. Bu ilişkiler balıkların av-avcı ilişkileri çalışmalarında tür tayini ve av boyu tahmininde önemli bilgiler sunduğundan, gelecekte gerçekleştirilecek mide içeriği çalışmaları açısından katkı sağlayacağını düşünmekteyiz.

Anahtar kelimeler: Sagital, kemiksi yapılar, doğrusal, boy, dip, algarna

\section{INTRODUCTION}

Fish bony structures detected in various environments are important for many disciplines. Bony structures of fish had been used by archaeologists as it gives insight into the feeding habits of the ancient excavations (O'Connor, 2000). Even so the most widely use of bony structures common for marine biology researches. Between of them, otoliths are known as the most useful bony structures (Pierce and Boyle, 1991). Otolithbody length relationships allow an identification and size estimation of fish in predator-prey studies. In stomach content analyses, the shape and biometry of otolith can give important information about the type of prey consumed by predator.
Beside the size of the prey can also be estimate from otoliths through using otolith-body length relationships (Granadeiro and Silva, 2000). However, there may not be a close relationship between otolith biometry and body measurements for all species (Simkiss, 1974; Lombarte and Lleonart, 1993). Therefore, for each fish species, these relationships should be calculated, otolith measurements should be specified and visual otolith atlas should be established. Since otolith shapes and sizes may vary according to regions, these studies should be performed separately for each region. Otolith atlas have been created, such as Campana (2004) approached in North 
American waters, Tuset et al. (2008) for the western Mediterranean, north and central eastern Atlantic, Assis (2000, 2004), on Portuguese coastal, estuarine and freshwater species. In Turkish seas, single atlas was presented by Kasapoğlu and Düzgüneş (2015) for Black Sea. The otolith images of 31 species in Black Sea coasts were presented. Among the species included in our study, only Uranoscopus scaber took part in this study without any relationships deal with otolith biometry-body length. Previous studies in Turkey on otolith biometry-fish length had been realized mostly on fresh water species (Şen et al., 2001; Aydın et al., 2004; BostancI, 2009; Başusta et al., 2013; Yılmaz et al., 2014; Bostancı et al., 2017). Şahin and Güneş (1998); Uçkun et al. (2006); Ceyhan and Akyol (2006); Bilge and Gülşahin (2014) and Bal et al. (2018) were studied otolith size-fish size relationships of marine fish species. The fish length and otolith length relationship of Solea solea was studied in İmir Bay (Hoşsucu et al., 1999), U. scaber in Spain coasts (Jaramillo et al., 2014); in Black Sea (Sağlam et al., 2014), Lophius budegassa in Greek waters (Tsimenidis and Ondrias, 1980), Lepidorhombus boscii in Aegean Sea (Bostancl and Polat, 2008), Lesueurigobius friesii in Aegean Sea (Illkyaz et al., 2011).

The aim of this study is to determine the relationships between fish length-otolith length, fish length-otolith width, fish length-otolith weight and fish weight-otolith weight of 7 demersal fish species from the Marmara Sea, Turkey. To our knowledge the results of this study will constitute the first results in the literature for Gaidropsarus biscayensis and Arnoglossus kessleri. In addition our results presents the first data in the Marmara Sea for all discussed fish species in this study.

\section{MATERIAL AND METHODS}

Between September 2011 and July 2014, fish were caught in Marmara Sea, Turkey with beam trawl equipped with a codend mesh size of $32 \mathrm{~mm}$. The tows were conducted at depths ranging from 50 to $150 \mathrm{~m}$ and tow duration was standardized to $1 / 2$ hour for all stations (Figure 1 ).

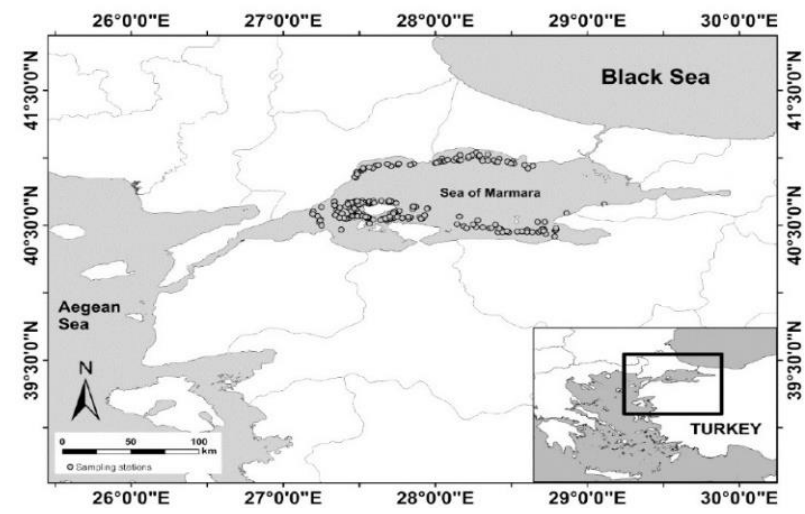

Figure 1. The trawl sampling stations from the Marmara Sea, Turkey
Behind the tows, individuals were preserved in a plastic case with ice, then delivered to the laboratory, immediately. The total length, total weight, otolith length, otolith width and otolith weight of $L$. friesii $(n=213)$, A. kessleri $\quad(n=164), \quad G$. biscayensis $(n=50)$, S. solea $(n=25), L$. boscii $(n=17), L$. budegassa $(n=15)$ and $U$. scaber $(n=13)$ were measured. Total length $(\mathrm{TL})$ and weight measurements were conducted in the laboratory to the nearest $0.1 \mathrm{~cm}$ and $0.01 \mathrm{~g}$, respectively. The otoliths (sagittae) were removed and measured under stereoscopic microscope to the nearest $0.1 \mathrm{~mm}(\mathrm{TL})$. The weight of otoliths (OW) were measured with $0.0001 \mathrm{~g}$ digital analytical balance precision scale. Lengths of sagittae (OL) were recorded as the greatest distance measured from the anterior tip to the posterior edge, parallel to the sulcus The width of sagitta (OWi) was determined by considering the greatest distance from the dorsal otolith edge to the ventral one, perpendicular to the sulcus (Harvey et al., 2000) (Figure 2).

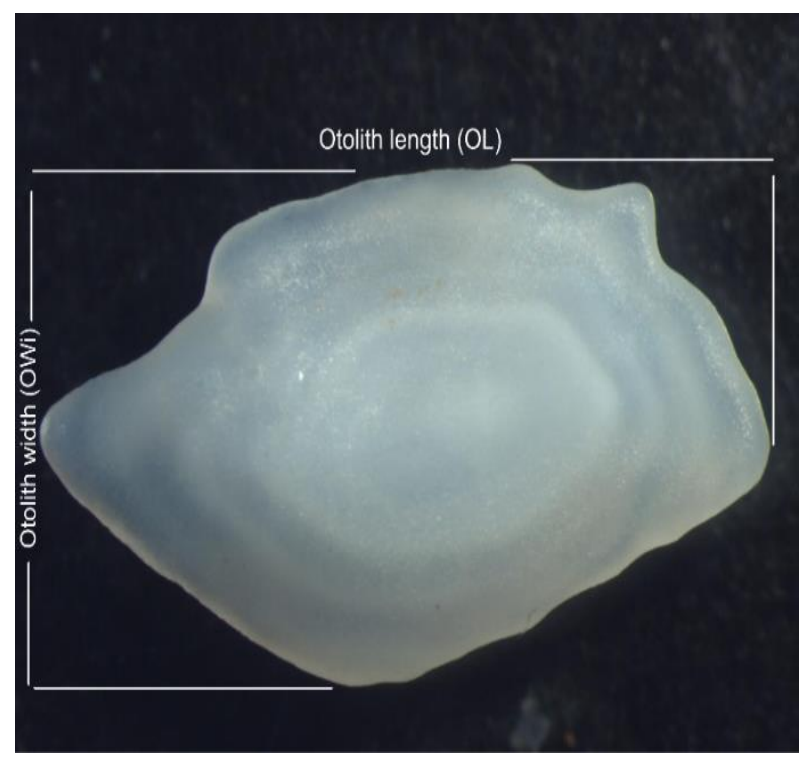

Figure 2. View of the otolith length and width measurements

The Student t-test (Zar, 1999) was used to compare between the length, width and weight of the right and left sagittal otoliths. No significant differences were detected for $L$. friesii, G. biscayensis, L. budegassa and U. scaber. So right otoliths were used in regression analyses. Due to metamorphosis, the otoliths of flat fish species (A. kessleri, $S$. solea and $L$. boscii) were showed significant differences and the blind ones were used in regression analyses.

Linear regression analysis $(y=b x+a)$ was used to determine the relationship between each morphometric character (TL-OL; TL-OWi; TL-OW; TW-OW) and the coefficient of determination $\left(r^{2}\right)$ were calculated. The F-test was used to determine the significance of the linear regressions. 


\section{RESULTS}

The length and weight intervals of 7 demersal fish species and length, width and weight intervals of sagittal otoliths can be seen in Table 1. In this study, a total of $213,164,50,25,17$, 15 and 13 individual of $L$. friesii, A. kessleri, G. biscayensis, $S$. solea, L. boscii, L. budegassa and U. scaber were analyzed, respectively. Highest otolith length, width and weight was observed for $U$. scaber. Although the individual sizes were small, the size of the otoliths were relatively large for $L$. friesii. It was determined that the otolith length and width of $L$. friesii individuals ranged between 2.447-4.235 and 1.934 and 3.433, respectively. The OL/TL ratio was calculated as $0.47,0.41$, $0.24,0.24,0.22,0.22$ and 0.19 for $L$. friesii, U. scaber, L. boscii, G. biscayensis, A. budegassa, A. kessleri, L. budegassa and S. solea, respectively.

The equations of relationship between each morphometric character (TL-OL; TL-OWi; TL-OW; TW-OW) were given in Table 2.
Also the equation curves of each species were shown in Figure $3,4,5,6,7,8$ and 9 . We observed relatively lower determination coefficient values for small sized species ( $L$. friesii, G. biscayensis and A. kessleri) compared with other higher sized ones. Both relationships of $L$. budegassa showed highest determination coefficient values. Between of them, the highest determination coefficient for $L$. budegassa was observed in TW-OW relationship. Also lineer relationship between TL-OL was best fit for $S$. solea with 0.92 determination coefficient value. Relatively strong relationship between TLOWi was detected for S. solea. The TL-OWi and TW-OW relationships were more meaningful for $L$. boscii with 0.85 and 0.84 determination coefficient values whereas TL-OWi and TLOL relationships were for $U$. scaber with 0.86 and 0.81 determination coefficient values. The TW-OW and TL-OW relationships were stronger than others for $A$. kessleri and $\mathrm{L}$. friesii, respectively. Although almost all relationships were weak, higher determination coefficient was seen in TL-OL for G. biscayensis (Table 2).

Table 1. The length, height and weight measurement of fish and otoliths

\begin{tabular}{lcccccccccc}
\hline \multirow{2}{*}{ Species } & \multicolumn{7}{c}{ Total Fish Length (TL) } & \multicolumn{7}{c}{ Total Fish Weight (TW) } & \multicolumn{7}{c}{ Otolith Length (OL) } & Otolith Width (OWi) & Otolith Weight (OW) \\
\cline { 2 - 20 } & Min & Max & Min & Max & Min & Max & Min & Max & Min & Max \\
\hline Lophius budegassa & 11.9 & 37.4 & 11.1 & 835.9 & 2.503 & 8.582 & 1.097 & 4.781 & 0.0010 & 0.0470 \\
Lepidorhombus boscii & 17.8 & 29.4 & 41.2 & 224 & 4.508 & 7.103 & 3.101 & 4.440 & 0.0167 & 0.0361 \\
Gaidropsarus biscayensis & 8.7 & 14.5 & 2.1 & 16.8 & 2.288 & 3.405 & 0.887 & 1.197 & 0.0007 & 0.0260 \\
Solea solea & 10.2 & 38 & 10.6 & 328.4 & 2.305 & 5.989 & 1.960 & 4.740 & 0.0038 & 0.0411 \\
Uranoscopus scaber & 9.2 & 20.6 & 13.3 & 176.8 & 3.305 & 9.298 & 1.898 & 5.064 & 0.0067 & 0.1172 \\
Arnoglossus kessleri & 6.8 & 11.6 & 2.3 & 17.7 & 1.607 & 3.516 & 1.150 & 2.261 & 0.0010 & 0.0104 \\
Lesueurigobius friesii & 4.9 & 9.3 & 1.2 & 5.1 & 2.447 & 4.235 & 1.934 & 3.433 & 0.0049 & 0.0268 \\
\hline
\end{tabular}

Table 2. The relationships between fish length-otolith length, fish length-otolith height, fish length-otolith weight and fish weight-otolith weight of seven species in Marmara Sea

\begin{tabular}{|c|c|c|c|c|c|c|c|c|c|}
\hline & $\mathrm{n}$ & TL-OL & $r^{2}$ & TL-OWi & $r^{2}$ & TL-OW & $r^{2}$ & TW-OW & $r^{2}$ \\
\hline Lophius budegassa & 15 & $\mathrm{TL}=4.5444 \mathrm{OL}-0.2643$ & 0.9357 & $\mathrm{TL}=7.0859 \mathrm{OH}+1.986$ & 0.8974 & $\mathrm{TL}=583.080 \mathrm{~W}+11.79$ & 0.934 & $T W=218010 W-272.22$ & 0.9545 \\
\hline Lepidorhombus boscii & 17 & $\mathrm{TL}=4.3810 \mathrm{~L}-1.7926$ & 0.7754 & $\mathrm{TL}=8.3795 \mathrm{OH}-8.1019$ & 0.8482 & $\mathrm{TL}=516.820 \mathrm{~W}+11.206$ & 0.7719 & $\mathrm{TW}=7806.40 \mathrm{~W}-70.764$ & 0.839 \\
\hline Gaidropsarus biscayensis & 50 & $\mathrm{TL}=4.08970 \mathrm{~L}+0.4166$ & 0.6606 & $\mathrm{TL}=11.9310 \mathrm{OH}-0.6848$ & 0.5323 & $\mathrm{TL}=2261.50 \mathrm{~W}+8.3393$ & 0.5533 & $\mathrm{TW}=4196.90 \mathrm{~W}+2.1756$ & 0.3076 \\
\hline Solea solea & 25 & $\mathrm{TL}=6.8386 \mathrm{OL}-5.2418$ & 0.9149 & $\mathrm{TL}=8.7389 \mathrm{OH}-5.4864$ & 0.8549 & $T L=503.390 \mathrm{~W}+13.454$ & 0.7479 & $T W=66320 W-9.5373$ & 0.7148 \\
\hline Uranoscopus scaber & 13 & $\mathrm{TL}=0.466 \mathrm{OL}-0.4788$ & 0.8175 & $\mathrm{TL}=0.253 \mathrm{OH}-0.3267$ & 0.8601 & $\mathrm{TL}=85.9360 \mathrm{~W}+11.206$ & 0.7476 & $T W=13620 W+10.259$ & 0.786 \\
\hline Arnoglossus kessleri & 164 & $\mathrm{TL}=4.032 \mathrm{OL}+1.0205$ & 0.7386 & $\mathrm{TL}=6.8394 \mathrm{OH}-0.3356$ & 0.6537 & $\mathrm{TL}=973.250 \mathrm{~W}+6.9362$ & 0.6911 & $T W=3633.70 \mathrm{~W}-2.7461$ & 0.7486 \\
\hline Lesueurigobius friesii & 213 & $\mathrm{TL}=2.1817 \mathrm{OL}-0.1263$ & 0.7016 & $\mathrm{TL}=2.5006 \mathrm{OH}+0.3903$ & 0.5288 & $T L=161.130 \mathrm{~W}+4.9885$ & 0.7196 & $T W=141.940 W+1.0818$ & 0.6173 \\
\hline
\end{tabular}


Arnoglossus kessleri
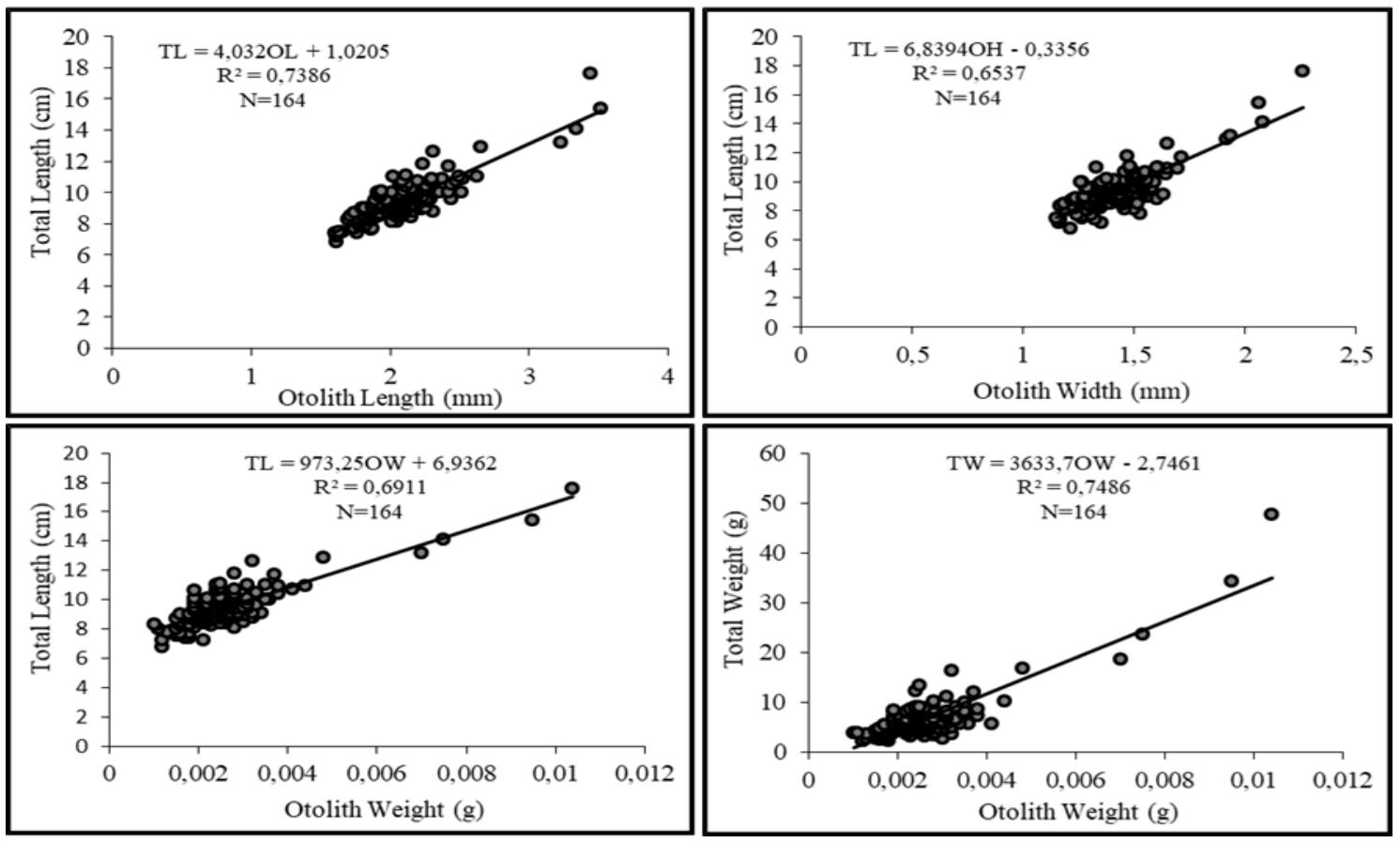

Figure 3. The relationships between TL-OL, TL-OWi, TL-OW and TW-OW of Arnoglossus kessleri from the Marmara Sea, Turkey

Gaidropsarus biscayensis

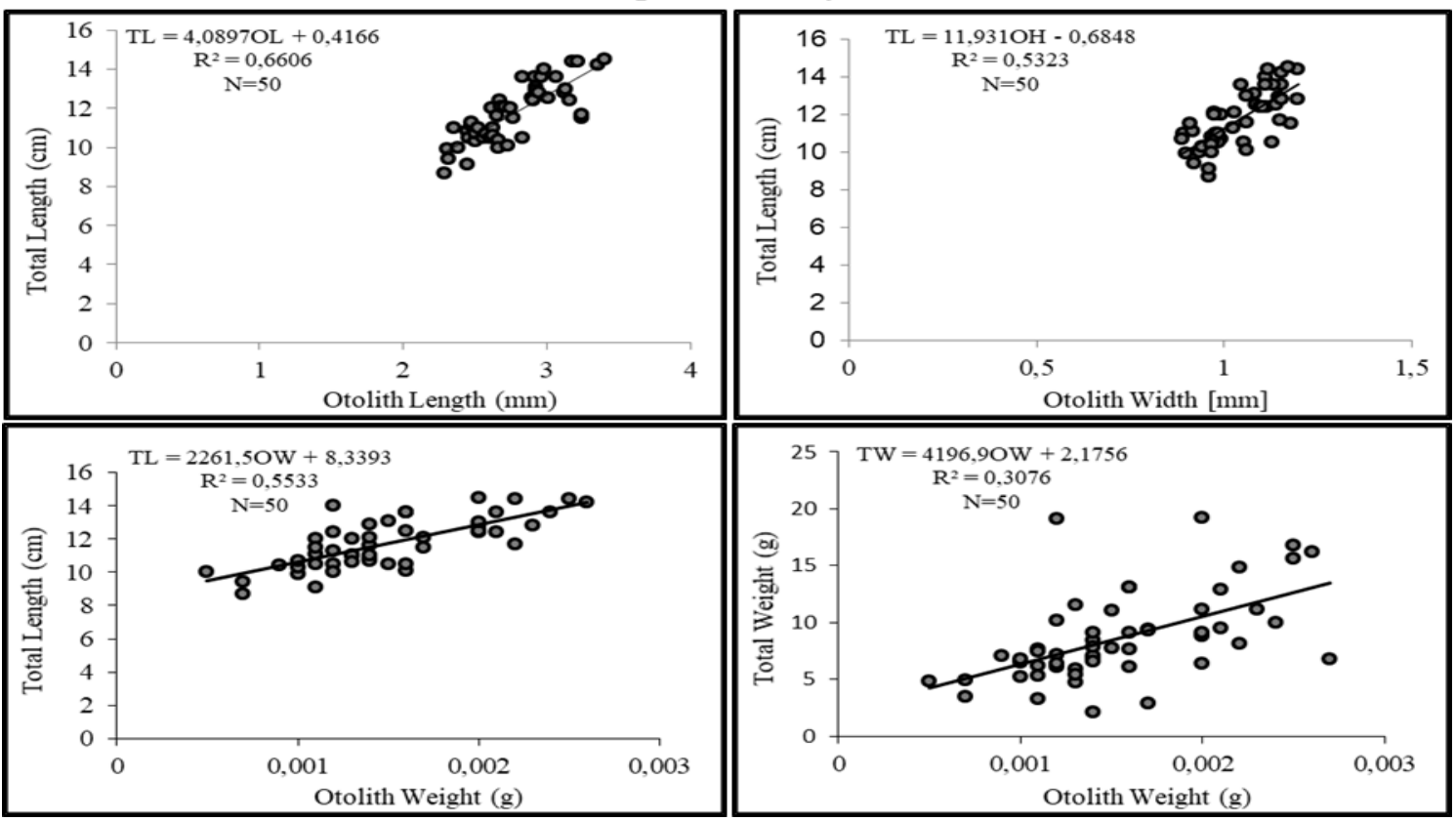

Figure 4. The relationships between TL-OL, TL-OWi, TL-OW and TW-OW of Gaidropsarus biscayensis from the Marmara Sea, Turkey 
Lophius budegassa

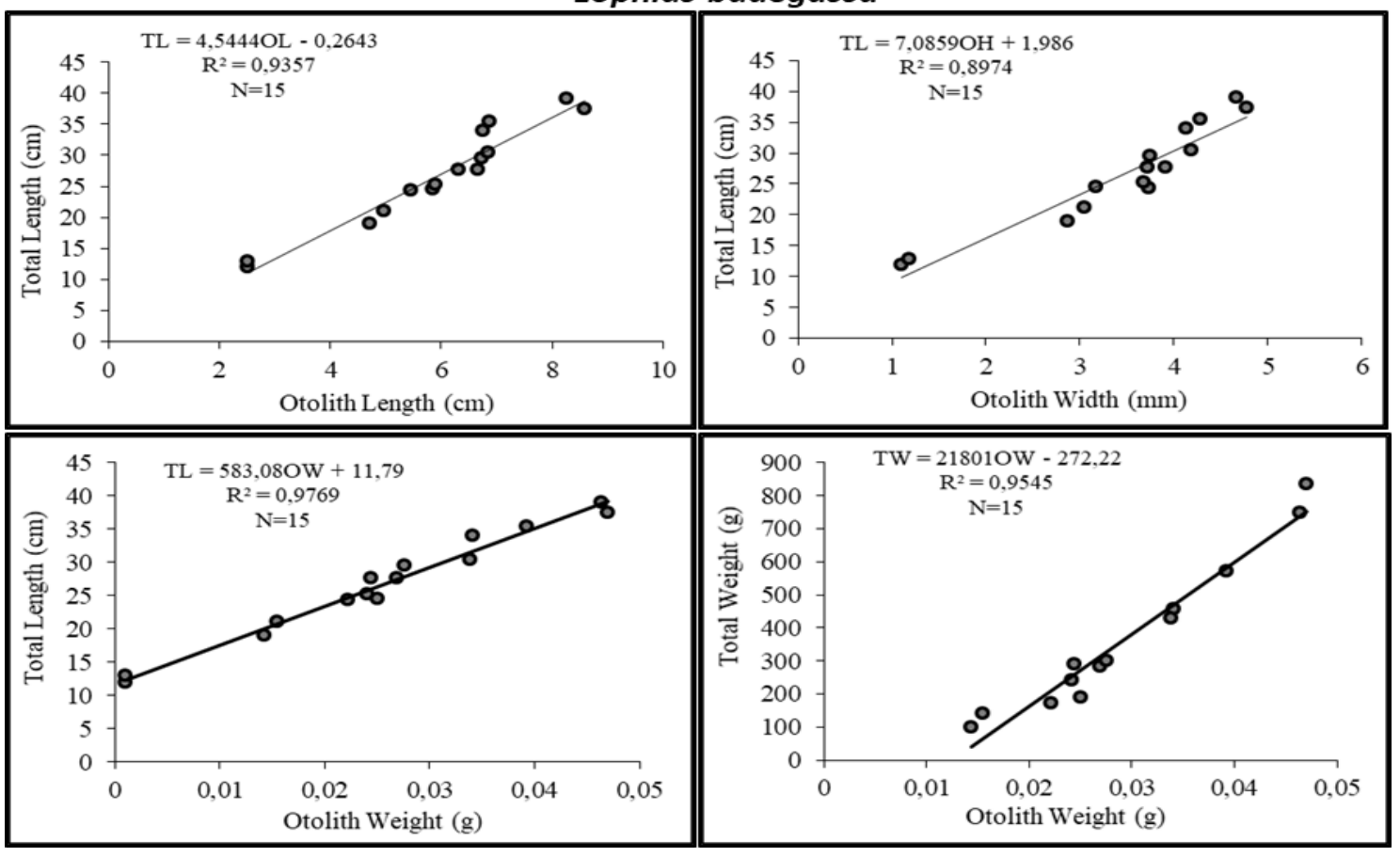

Figure 5. The relationships between TL-OL, TL-OWi, TL-OW and TW-OW of Lophius budegassa from the Marmara Sea, Turkey

\section{Lepidorhombus boscii}

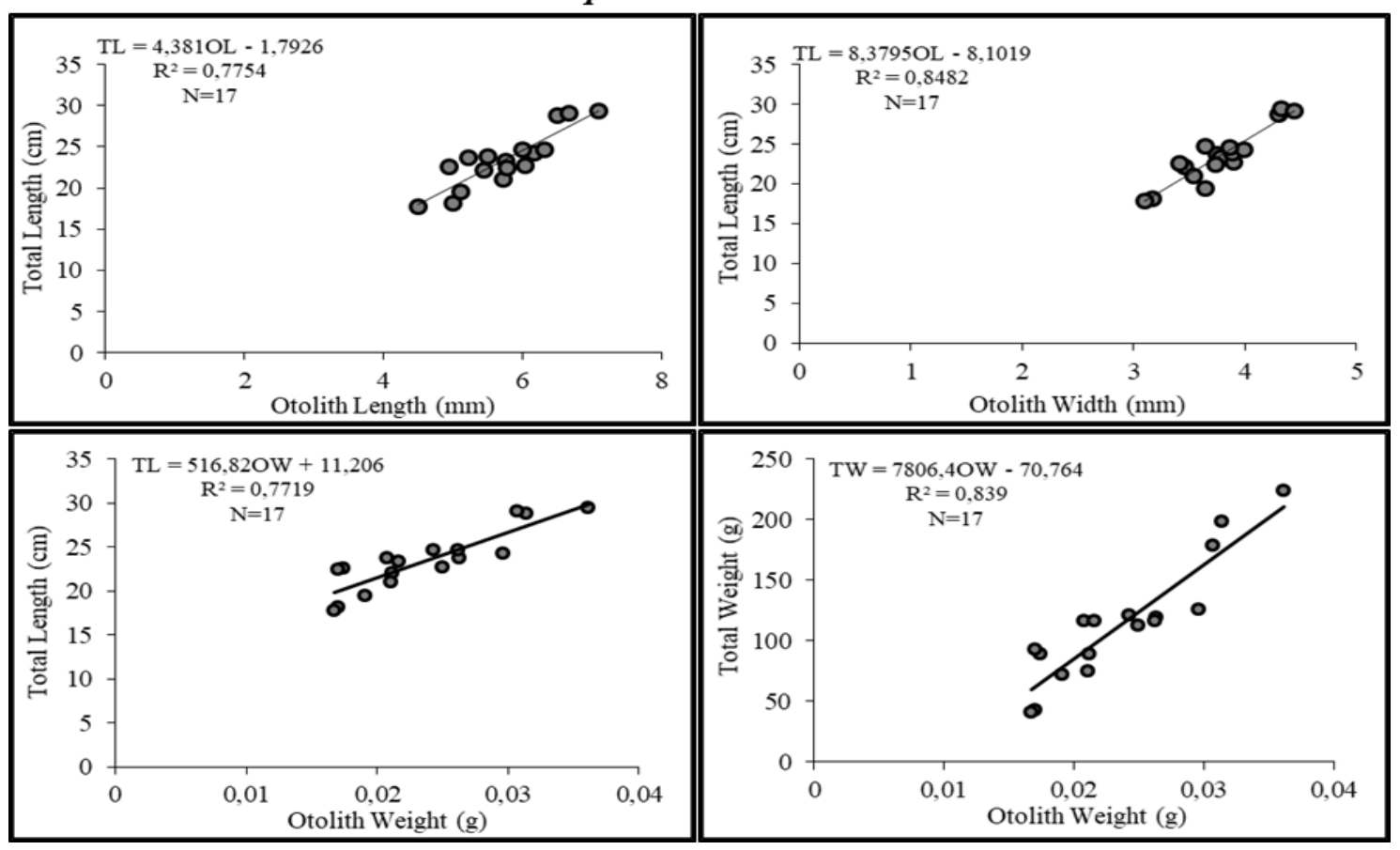

Figure 6. The relationships between TL-OL, TL-OWi, TL-OW and TW-OW of Lepidorhombus boscii from the Marmara Sea, Turkey 


\section{Lesueurigobius friesii}

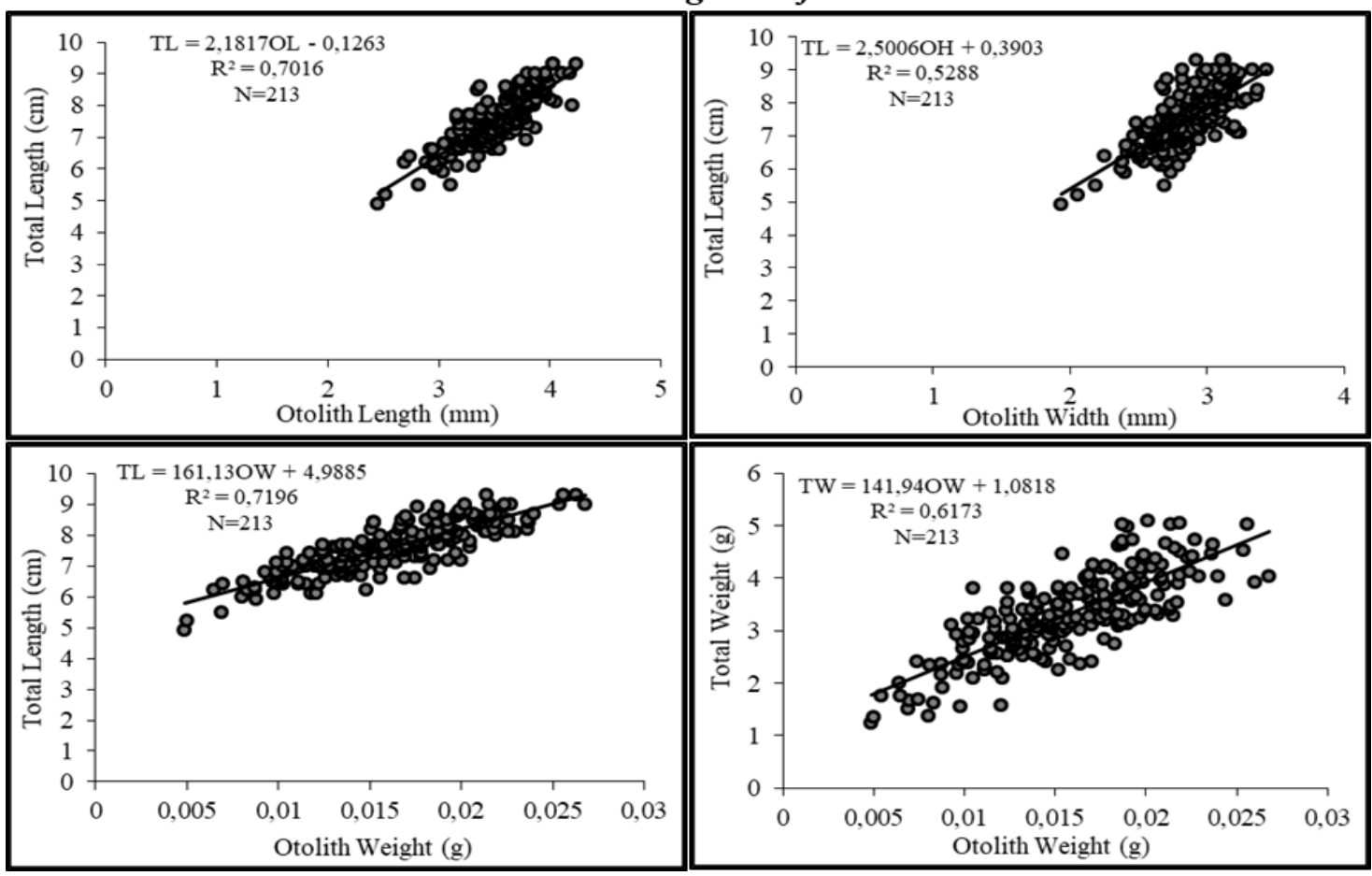

Figure 7. The relationships between TL-OL, TL-OWi, TL-OW and TW-OW of Lesueurigobius friesii from the Marmara Sea, Turkey

\section{Solea solea}
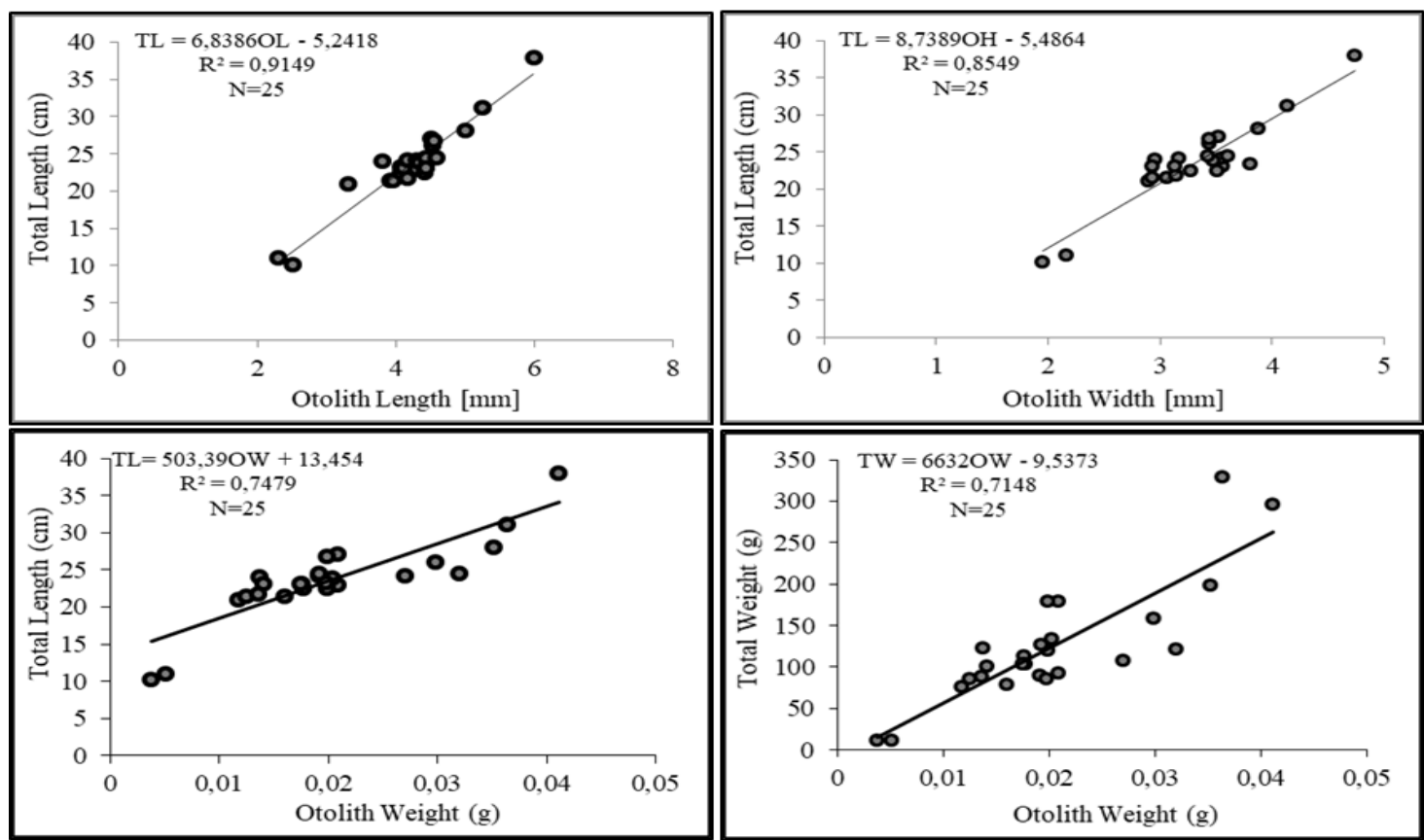

Figure 8. The relationships between TL-OL, TL-OWi, TL-OW and TW-OW of Solea solea from the Marmara Sea, Turkey 


\section{Uranoscopus scaber}

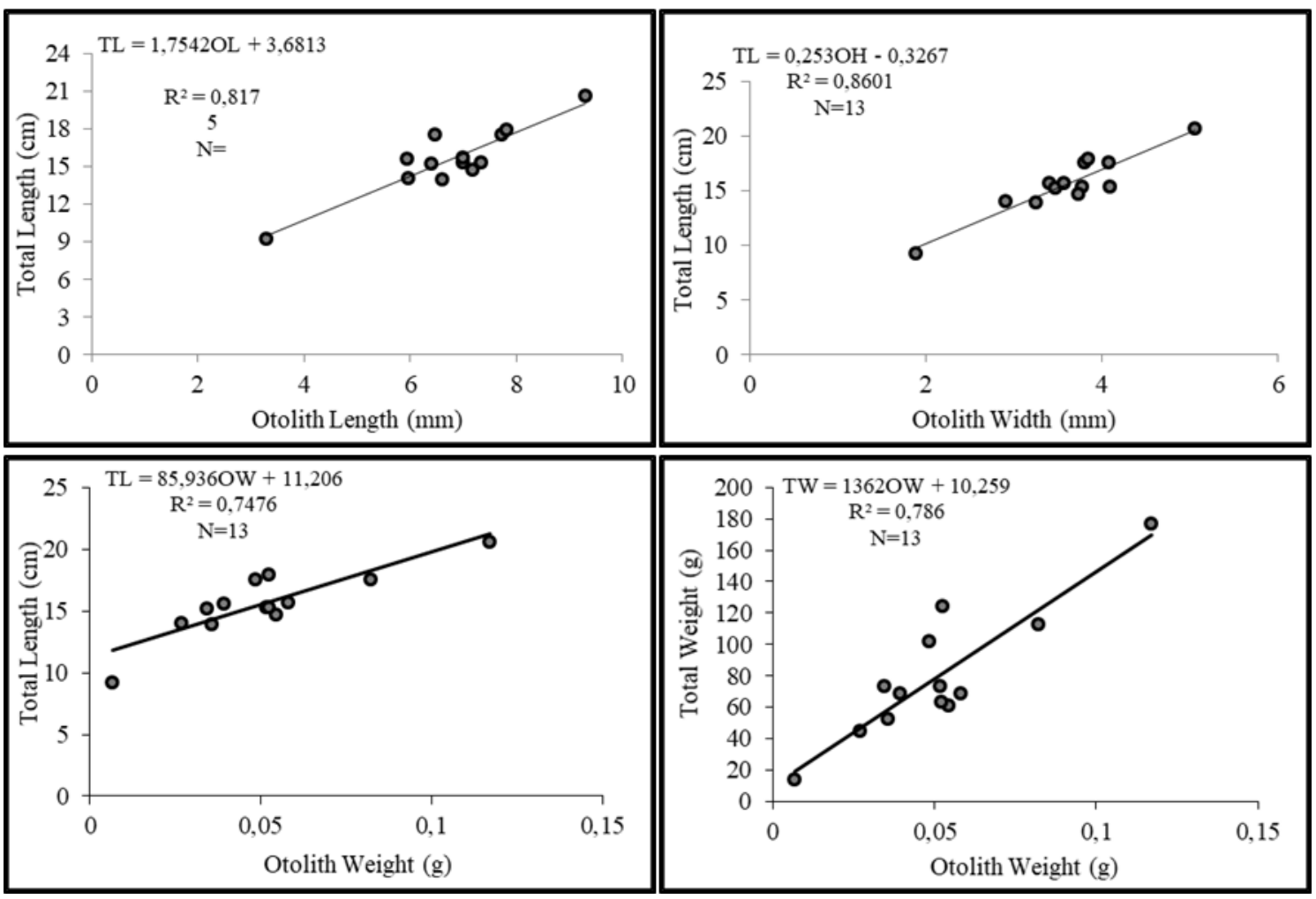

Figure 9. The relationships between TL-OL, TL-OWi, TL-OW and TW-OW of Uranoscopus scaber from the Marmara Sea, Turkey

\section{DISCUSSION}

The species that analyzed in this study represented important components of demersal food competition of the Marmara Sea, Turkey. These species were chosen because of the possibility of being prey because of its relatively small size compared to others. Beside limited number of studies were conducted deal with the fish size-otolith size relationships.

Hoşsucu et al. (1999) were found lineer relationship for $S$. solea in Izmir Bay between fish length and otolith length. Bostanci and Polat (2008) were determined lineer relationships between TL-OL, TL-OWi and TL-OW from L. boscii individuals that the length interval varied between 15.5 and 22.7. The relationships from this study were in agreement with our findings. The calculated lower $a$ and $b$ values in that study via our results may arised from limited length interval. Cengiz et al. (2013) were studied the growth parameters of $L$. boscii in Saros Bay, north Aegean Sea from the individuals varied from 10.9 to $40.8 \mathrm{~cm} \mathrm{TL}$. According to authors, the $L \infty$ values were estimated for females and males as 49.8 and $39.1 \mathrm{~cm} \mathrm{TL}$, respectively. During three year sampling, we could not sampled any $L$. boscii individual greater than $29.4 \mathrm{~cm} \mathrm{TL}$. This may be stemmed from the lower fishing effort on demersal species in Saros Bay due to restricted area for trawling. Similar lineer relationships were reported by Illkyaz et al. (2011) for $L$. friesii in İzmir Bay, Aegean Sea but the main difference is that the maximum length and weight of the otolith measurements. The reason for the difference may be attributed to greater individual sizes. Our results coincide with the findings of Sağlam et al. (2014) in Black Sea for U. scaber fish lengthotolith length and fish length-otolith width lineer relationships with high determination coefficient. In that study the authors were calculated TW-OW relationship as power equation. Unlike we found greater determination coefficient for TW-OW lineer relationship rather than power equation. According to age-mean length and age-mean otolith weight keys of Sağlam et al. (2014), the back-calculated age interval of the U. scaber in Marmara Sea estimated between 0 and 3 with a great majority of 1 and 2 ages. The relatively same equation and determination coefficient was calculated for $U$. scaber with the study conducted by Jaramillo et al. (2014) in Spain coasts. Tsimenidis and Ondrias (1980) were determined also lineer relationship with total length and otolith radius for $L$. budegassa in Greek waters as our TL-OL relationship.

The results of the small sized species were highly important due to they constitutes great amount of prey of carnivor species. In this respect, L. friesii, G. biscayensis and A. kessleri, which has high biomass with deep water rose shrimp, Parapenaeus longirostris, comprising the most 
important food source of other carnivor species in Marmara Sea.

Due to the fish length-otolith length studies provide vital information on species identification and size estimation of fish in predator-prey studies, we believe these results will be useful in future studies of stomach contents.

\section{REFERENCES}

Assis, C.A. (2000). Estudo morfológico dos otólitos sagitta, ssteriscus e lapillus de Teleósteos (Actinopterygii, Teleostei) de Portugal continental. PhD thesis, Sua aplicação em estudos de filogenia, fistemática e ecologia, University of Lisbon.

Assis, C.A. (2004). Guia para a identificação de algumas famílias de peixes ósseos de Portugal continental, através da morfologia dos seus otólitos sagitta. Câmara Municipal de Cascais, Cascais.

Aydın, R., Calta, M., Sen, D. \& Coban, M.Z. (2004). Relationships between fish lengths and otolith length in the population of Chondrostoma regium (Heckel, 1843) inhabiting Keban Dam Lake. Pakistan Journal of Biological Sciences, 7(9), 1550-1553. DOI: 10.3923/pjbs.2004.1550.1553

Bal, H. Yanık, T. \& Türker, D. 2018. Relationships between total length and otolith size of bluefish Pomatomus saltatrix (Linnaeus, 1766) in the Marmara Sea of Turkey. Natural and Engineering Sciences 3(1): 38-44. DOI: $10.28978 /$ nesciences.379319

Başusta, A., Bal, H. \& Aslan, E. (2013). Otolith Biometry - Total Length Relationships in the Population of Hazar Bleak, Alburnus heckeli (Battalgil, 1943) Inhabiting Lake Hazar, Elazig, Turkey. Pakistan Journal of Zoology, 45(4), 1180-1182.

Bilge, G. \& Guilșahin, A. (2014). Relationship between sagittal otolith size and fish size in Argentina sphyraena and Glossanodon leioglossus (Osteichthyes: Argentinidae) in the southern Aegean Sea, Turkey. Zoology in the Middle East 60 (1): 24-28. DOI: 10.1080/09397140.2014.892327

Bostancl, D. (2009).Otolith Biometry-Body Length Relationships in Four Fish Species (Chub, Pikeperch, Crucian carp, and Common Carp), Journal of Freshwater Ecology, 24(4), 619-624. DOI: $10.1080 / 02705060.2009 .9664339$

Bostancı, D. \& Polat, N. (2008). Otolith structure, otolith dimensions-fish length relationships and age determination of fourspotted megrim Lepidorhombus boscii, (Risso, 1810). Journal of Fisheries Sciences, 2(3), 375-381. DOI: 10.3153/jfscom.mug.200726

Bostancı, D., Yedier, S., Kontaş, S., Kurucu, G. \& Polat, N. (2017). Regional variation of relationship between total length and otolith sizes in the three Atherina boyeri Risso, 1810 populations, Turkey. Ege Journal of Fisheries and Aquatic Sciences, 34(1), 11-16. DOI:10.12714/egejfas.2017.34.1.02

Campana, S.E. (2004). Photographic atlas of fish otoliths of the Northwest Atlantic ocean. Canadian Special Publication Journal of Fisheries and Aquatic Sciences, 133, 1-284. DOI: 10.1139/9780660191089

Cengiz, Ö., Özekinci, U., İşmen, A. \& Öztekin, A. (2013). Age and growth of the four-spotted megrim (Lepidorhombus boscii Risso, 1810) from Saros Bay (Northern Aegean Sea, Turkey). Mediterranean Marine Sciences, 14(1), 36-44. DOI: $10.12681 / \mathrm{mms} .328$

Ceyhan, T. \& Akyol, O. (2006). Age distribution and relationship between fork length and otolith length of bluefish (Pomatomus saltatrix L., 1766) in the Sea of Marmara. Ege Journal of Fisheries and Aquatic Sciences, 23 (Suppl. 1/3): 369-372.

Granadeiro, J.P. \& Silva, M.A. (2000). The use of otoliths and vertebrae in the identification and size-estimation of fish in predator-prey studies. Cybium, 24, 383-393.

Harvey, J.T., Loughlin, T.R., Perez, M.A. \& Oxman, D.S. (2000). Relationship between fish size and otolith length for 63 species of fishes from the eastern north Pacific Ocean. NOAA Techinal Reports NMFS, 150, pp. 35.

\section{ACKNOWLEDGMENT}

This project supported by General Directorate of Agricultural Research and Policy of Turkey with the project number TAGEM/HAYSUD/2011/09/02/04. The authors would like to thank the researchers, Şükriye Ana vessel captain and crew.

Hoşsucu, B., Kaya, M. \& Taşkavak, E. (1999). An Investigation of Growth Parameters and Otolith-Total Length Relationship of Solea Solea (L.,1758) (Pisces: Soleıdae) in Izmır Bay. Israel Journal of Zoology, 45(2), 277-287.

İlkyaz, A.T., Metin, G. \& Kinacıgil, H.T. (2011). The use of otolith length and weight measurements in age estimations of three Gobiidae species (Deltentosteus quadrimaculatus, Gobius niger, and Lesueurigobius friesii). Turkish Journal of Zoology, 35, 819-827.

Jaramillo, A.M., Tombari, A.D., Dura, V.B., Rodrigo, M.E. \& Volpedo, A.V. (2014). Otolith Eco-Morphological Patterns of Benthic Fishes from the Coast of Valencia (Spain)., 30(1), 57-66.

Kasapoğlu, N. \& Düzgüneş, E. (2015). Otolith Atlas for the Black Sea. Journal of Environmental Protection Thalassas and Ecology (Marine ecology), 16 (1), 133-144.

Lombarte, A. \& Lleonart, J. (1993). Otolith size changes related with body growth, habitat depth and temperature. Environmental Biology of Fishes, 37: 297-306. DOI: 10.1007/BF00004637

O'Connor, T.P. (2000): The Archaeology of Animal Bones. Stroud: Sutton.

Pierce, G.J. \& Boyle, P.R. (1991). A review of methods for diet analysis in piscivorous marine mammals. Oceanography and Marine Biology, An Annual Review, (London), 29, 409-486.

Sağlam, N.E., Sağlam, C. \& Sağlam, Y.D. (2014). The Relationship Fish Size and Otolith Dimensions of Stargazer (Uranoscopus scaber) in the Southeastern Black Sea. Journal of Marine Biological Association of the United Kingdom, 94(05), 1041-1045. DOI: 10.1017/S0025315414000381

Şahin, T. \& Güneş, E. (1998). Relationship between otolith and total lengths of flounder (Pleuronectes flesus luscus Palas, 1811) collected in eastern Black Sea Coast of Turkey, Turkish Journal of Marine Sciences, 4: 117123.

Şen, D., Aydin, R. \& Calta, M. (2001). Relationships Between Fish Length and Otolith Length in the Population of Capoeta capoeta umbla (Heckel, 1843) Inhabiting Hazar Lake, Elazıg, Turkey. Archives of Polish Fisheries, 9(2), 267-272.

Simkiss, K. 1974. Calcium metabolism of fish in relation to age- ing. pp.l-12. In: T.B. Bagenal (ed.) Ageing of Fish, Unwin Brothers, Old Woking.

Tsimenidis, N.Ch. \& Ondrias, J.Ch. (1980). Growth studies on the angler-fishes $L$. piscatorius and $L$. budegassa in Greek waters. Thalasographica, 2(3),63-94.

Tuset, V.M., Lombarte, A. \& Assis, C.A. (2008). Otolith atlas for the western Mediterranean, north and central eastern Atlantic. Scientia Marina, 72(S1): 7-198. DOI: 10.3989/scimar.2008.72s17

Uçkun, D., Taşkavak, E. \& Toğulga, M. (2006). A preliminary study on otolithtotal length relationship of the common hake (Merluccius merluccius L., 1758) in izmir Bay, Aegean Sea. Pakistan Journal of Zoology., 9(9): 17201725. DOI: $10.3923 / p j b s .2006 .1720 .1725$

Yilmaz, S., Yazicioglu, O., Saygin, S.A. \& Polat, N. (2014). Relationships of Otolith Dimensions with Body Length of European Perch, Perca fluviatilis L., 1758 From Lake Ladik, Turkey. Pakistan Journal of Zoology, 46(5), 1231-1238.

Zar, J.H. (1999). Biostatistical analysis. Prentice Hall, Engelwood Cliffs, N.J., USA. 